\title{
Implementation of the Semi-Distributed SWAT (Soil and Water Assessment Tool) Model Capacity in the Lobo Watershed at Nibéhibé (Center-West of Côte d'Ivoire)
}

\section{Tanoh Jean-Jacques Koua ${ }^{1,2}$, Yeganantham Dhanesh'2, Jaehak Jeong ${ }^{3}$, Raghavan Srinivasan ${ }^{2,3}$, Kouao Armand Anoh ${ }^{1}$}

${ }^{1}$ Jean Lorougnon Guédé University, Environmental Sciences and Technologies Laboratory, Daloa, Côte d'Ivoire

${ }^{2}$ Texas A \& M University, Spatial Sciences Laboratory, College Station, Texas, USA

${ }^{3}$ Texas A \& M AgriLife Research, Temple, Texas, USA

Email: *kouatanoh7@gmail.com

How to cite this paper: Koua, T. J.-J., Dhanesh, Y., Jeong, J., Srinivasan, R., \& Anoh, K. A. (2021). Implementation of the SemiDistributed SWAT (Soil and Water Assessment Tool) Model Capacity in the Lobo Watershed at Nibéhibé (Center-West of Côte d'Ivoire). Journal of Geoscience and Environment Protection, 9, 21-38. https://doi.org/10.4236/gep.2021.98002

Received: June 19, 2021

Accepted: August 6, 2021

Published: August 9, 2021

Copyright $\odot 2021$ by author(s) and Scientific Research Publishing Inc. This work is licensed under the Creative Commons Attribution International License (CC BY 4.0).

http://creativecommons.org/licenses/by/4.0/

\section{Open Access}

\begin{abstract}
The Lobo watershed is an agricultural area where the use of fertilizers by farmers is intensive, causing eutrophication problems that deteriorate the quality of drinking water distributed to the population. Since the phenomenon of eutrophication is directly linked to runoff, it is essential to model the flow in order to better control the transfer of nutrients responsible for eutrophication. It is within this framework that this study was conducted. The objective of this study is to assess the ability of the semi-distributed SWAT (Soil and Water Assessment Tool) model to simulate runoff in the Lobo watershed. The methodology adopted was based on the use of the QSWAT graphical interface to manipulate and execute the main functions of the SWAT model from QGIS tools. The hydrological modeling was carried out with the QSWAT interface for SWAT 2012. The results showed good performance for the flow calibration (1982-1984) with the evaluation criteria $R^{2}$, NSE and PBIAS respectively of $0.64,0.64$ and 3.1. In the validation period (1984-1987), the model also showed good performance in the streamflow simulation for $\mathrm{R}^{2}$ and NSE of 0.84 and 0.76 respectively as values. However, for the PBAIS criterion, the result was less good but still remains satisfactory with a value of 19.6. It emerges from this study that the SWAT model is suitable for simulating water transfer and can therefore be used to study the transfer of pollutants in the fight against eutrophication in the Lobo watershed.
\end{abstract}




\section{Keywords}

Modelling, SWAT, Lobo, Eutrophication, Côte d'Ivoire

\section{Introduction}

According to FAO statistics, $42 \%$ of the world's population lived at the start of this new millennium from agriculture, hunting, fishing and forestry. Agriculture is still the engine of the economy of most developing countries, it is also for industrialized countries such as the USA where exports in 2001 reached 290 billion dollars. In human history, few countries have experienced rapid economic growth without significant progress in previous agricultural development.

Côte d'Ivoire is a country with a predominantly rural population (60\%) with $30.7 \%$ of the GDP (Gross Domestic Product) coming from the agricultural sector. This is why several state establishments such as ANADER, CNRA, the Office for the Marketing of Food Products (OCPV) and the National Office for the Development of Rice Cultivation (ONDR) have been set up by the State to supervise and support farmers. With galloping population growth and constantly increasing demand, the State of Côte d'Ivoire has implemented an incentive policy through these agencies to use phyto-sanitary products and fertilizers in order to increase their agricultural productivity. However, failure to observe the principles of environmental protection has led to the uncontrolled use of these products. This irresponsible use has led the rest of these products in the hydrographic network, causing major eutrophication problems. Numerous authors have studied eutrophication phenomenon among which one can cite (Vinçon-Leite \& Casenave, 2019; Moal, et al., 2019; Bhagowati \& Ahamad, 2019). These authors have shown that the main surface water quality problem comes from eutrophication mainly in developing countries. The combat against such phenomenon will be more effective by the use of hydrological models to assess runoff, nutrients and its sources responsible of eutrophication (Garnier et al., 2018; Babaei et al., 2019).

In Côte d'Ivoire, research by (Komelan, 1999; Maiga et al., 2001; Dié, 2006; Ohou et al., 2014) has proved by analysis of biological and physicochemical parameters advanced eutrophication of the Lobo reservoir. These studies, although important, have not made it possible to clearly understand the origin and the spatio-temporal evolution of the eutrophication phenomenon in the Lobo watershed. To overcome this lack, methodologies based on the use of hydrological models and Geographic Information Systems (GIS) have been adapted under these conditions. Hydrological processes in watersheds are generally described by several types of models: the physical-based conceptual model, the empirical model and the semi-distributed model. In the physical-based conceptual model, the functioning of the basin is based on an analogy and a concept. The analogy 
uses the principle that soils and groundwater function as reservoirs whose discharge rate depends on the rate of filling (Chocat, 1997; Refsgaard, 1997). The empirical model based on a precise and empirical physical representation is developed from experiments in the laboratory or in the field (Refsgaard \& Storm, 1996): USLE erosion model (Universal Soil Loss Equation) (Wischmeier, 1978). Also, these two types of models are global and represent the watershed as a single entity and attempt to reproduce its general behavior. Unfortunately, the global model is not suited to the study of hydrological processes in agricultural watersheds. This model cannot take into account the spatial variability of phenomena such as runoff or erosion and therefore is unable to assess the effects of changes in land use on runoff. Thus, semi-distributed models, such as the Soil and Water Assessment Tool (SWAT), have been developed in order to consider the spatial variability of the phenomena acting on the basin.

The aim of this study is to assess the capacity of the SWAT agro-hydrological model to simulate the flow in an agricultural watershed with uncontrolled use of phytosanitary products and fertilizers.

\section{Materials and Methods}

\subsection{Materials}

\subsubsection{Study Area}

The Lobo watershed in Nibéhibé is located between $6^{\circ} 00^{\prime \prime}$ and $7^{\circ} 00^{\prime \prime}$ west longitude and 6v54" and $8^{\circ} 00^{\prime \prime}$ north latitude and drains an area of $6442.66 \mathrm{~km}^{2}$ (Figure 1). It is a less rugged region with plateaus of around 200 to $400 \mathrm{~m}$ above sea level (Avenard, 1971). The geological formations encountered are granite

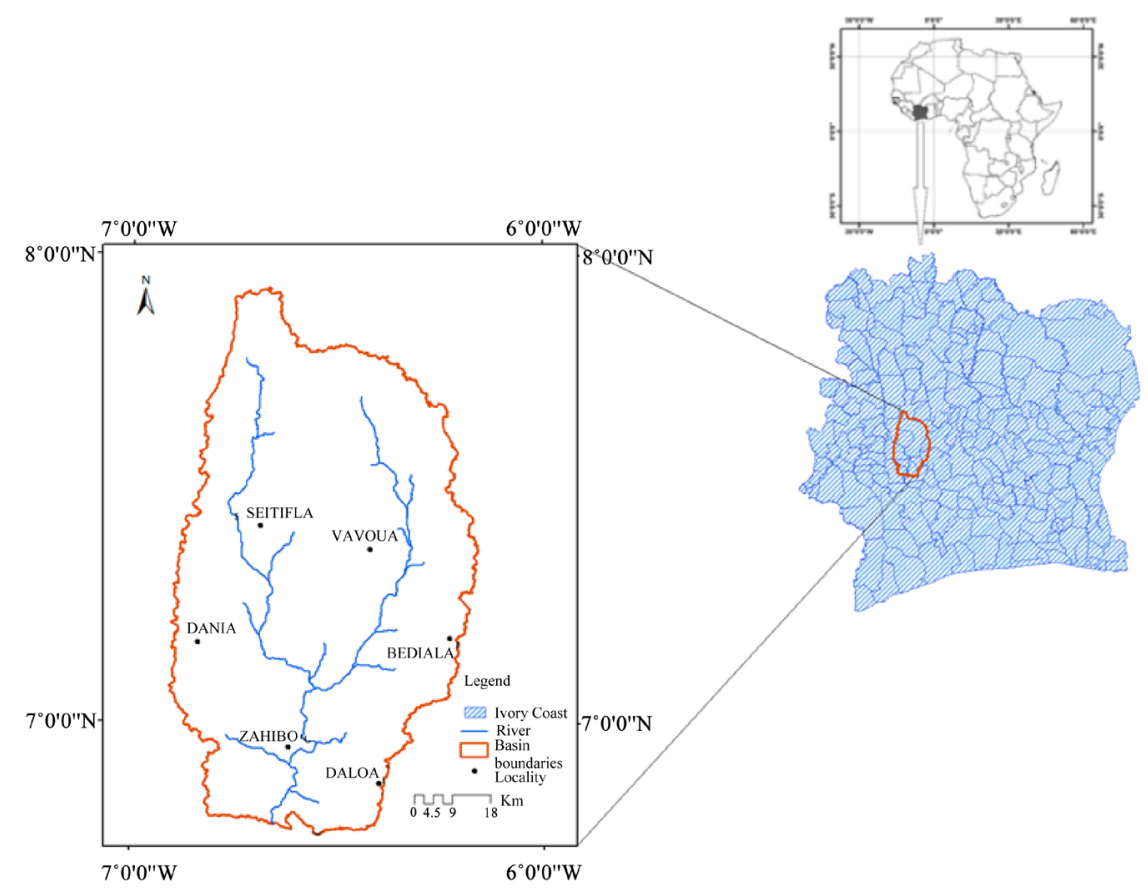

Figure 1. Lobo basin location. 
with schist and flysch intrusions. There are two great seasons. The dry season is from November to February and the rainy season is from March to October. The long rainy season is observed from March to June and the short season from July to October. The annual water balance shows $1518.5 \mathrm{~mm}$ of rain, a runoff of 236 $\mathrm{mm}$, an infiltration of $456 \mathrm{~mm}$ and actual evapotranspiration of $805 \mathrm{~mm}$ (Koua et al., 2019).

This area is covered by dense humid semi-deciduous forest. The ferralitic soil, strongly or moderately, offers an agricultural activity based on perennial cash crops (coffee, cocoa, rubber, oil palm) and food crops (Brou, 2005). The drinking water supply to the populations is ensured by SODECI's water supply systems from the Lobo reservoir.

\subsubsection{Data}

Several data were used to carry out this study. Among other data, we can cite the Digital elevation model (DEM), the land use map, the soil map and its physicochemical and biological properties, climatic data (Figure 2) and agronomic data. The $30 \mathrm{~m} \times 30 \mathrm{~m}$ resolution digital elevation model (DEM) was obtained from https://search.earthdata.nasa.gov/search. It was used to delineate the watershed and extract the hydrographic network. The land use map comes from the processing of four (4) sentinel-2 satellite images downloaded from the site https://scihub.copernicus.eu/dhus/\#/home taken on February 22, 2018 (resolution of $10 \mathrm{~m}$, under UTM, Zone 30, projection in the northern hemisphere) using ENVI 4.7. Five land use classes were obtained: dense forest (11\%), degraded forest (9\%), agriculture and fallow (77\%), urban (0.5\%) and water (2.5\%). In addition to the soil map, the physicochemical characteristics of the soil such as texture, available water content, hydraulic conductivity, bulk density and organic carbon content of the different soil layers from the FAO database (Nachtergaele et al., 2009) and obtained in the field and in laboratory, were used to run the model. The watershed is dominated by the clay-sandy loam of the Orthic Acrisol group with $38 \%$, followed by the sandy loam soil of the Ferric Acrisol representing $32 \%$ of the basin. The meteorological data used at daily time step including minimum and maximum temperatures, precipitation, relative humidity, solar radiation and wind speed come from the website http://globalweather.tamu.edu/. Eleven (11) climate stations were used, with data covering the period 1979-2014. The agronomic data used for this study are the types of fertilizers and the doses applied to each crop, the types of crops and agricultural practices in the watershed and the agricultural calendars. The information is taken from the technical sheets of the National Agronomic Research Center of Côte d'Ivoire (CNRA) (Koua et al., 2019).

\subsubsection{Computer Software}

QSWAT 1.9 in the QGIS 2.6.1 interface was used to delineate the watershed and sub watersheds, extract the river system, and simulate water flow. SWAT-CUP2019 (Calibration Uncertainty Program) has been used to calibrate and validate the water flow. 
T. J.-J. Koua et al.

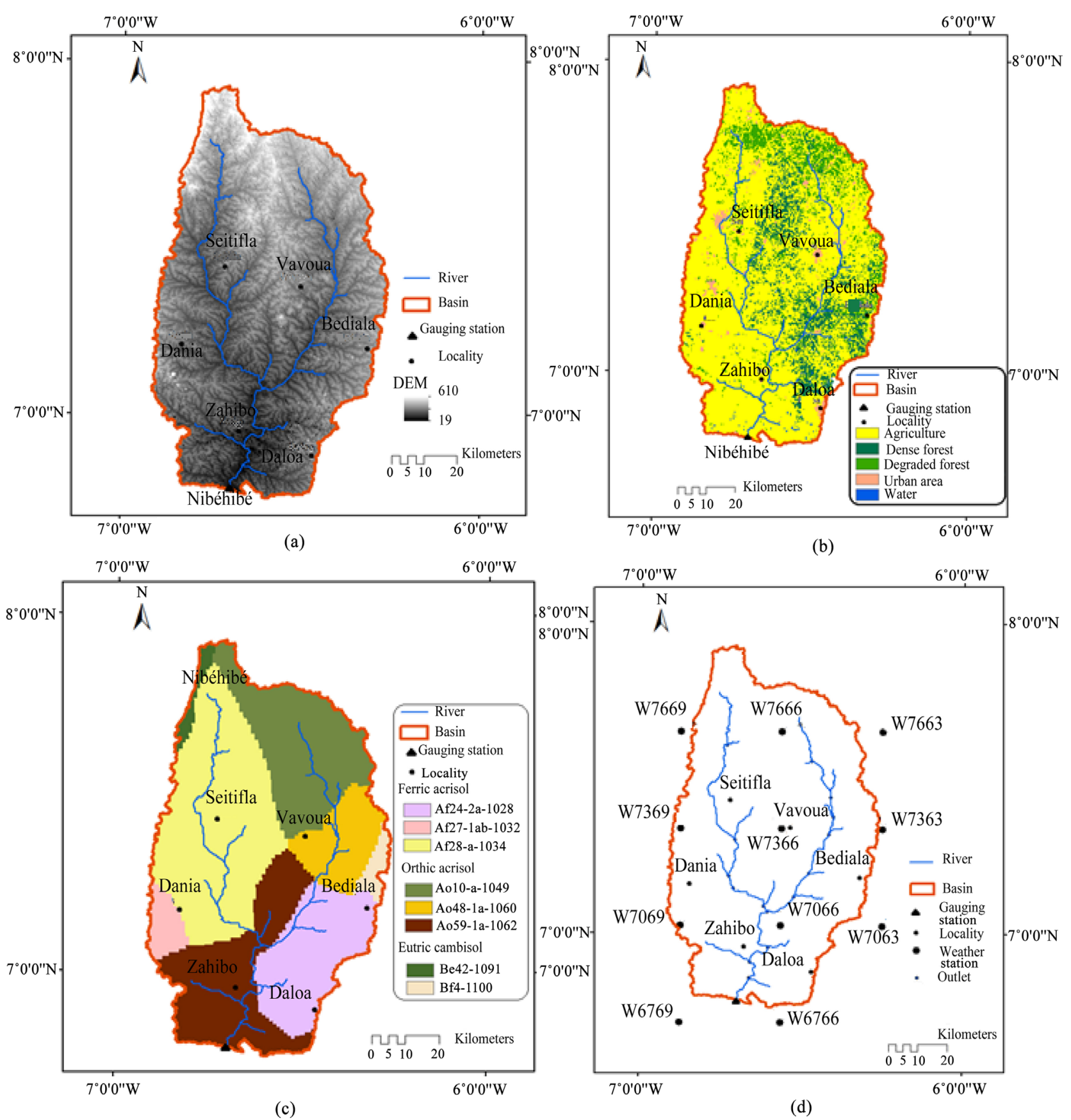

Figure 2. Four major essential data of SWAT model: (a) Digital Elevation Model; (b) Land use; (c) Soil; (d) Climate and Hydrological data.

The ENVI 4.7 software allowed the digital processing of satellite images to obtain the land use map and the WGN parameters Estimation Tool software was used to calculate the statistical parameters of the climate data.

\subsection{Methods}

The methodology used in this study is based on the SWAT (Soil and Water Assessment Tool) model. 


\subsubsection{Model and Software Description}

\section{1) SWAT model description}

SWAT (Soil and Water Assessment Tool) is a semi-distributed agro-hydrological model (Arnold et al., 1998) which operates on a daily time step. It has been used worldwide for water management (quality and quantity), agricultural practices management, large watersheds simulation, surface water and subsurface management and sediment, nutrient and pesticide processes modeling. SWAT is supported by a large scientific community. SWAT is based upon water balance Equation (1) from (Neitsch et al., 2005). Hydrological simulation of a watershed can be divided into two (2) major parts. The first division is the land phase of the hydrologic cycle (Figure 3).

The land phase of hydrologic cycle controls the amount of water, sediments, nutrients and pesticides loads to the main channel in each subbasin.

The second division is the water or routing phase of hydrologic cycle related to the movement of water, sediments, nutrients and pesticides, etc. through the channel network of the watershed to the oulet (Neitsch et al., 2011).

$$
S W t=S W o+\Sigma(R d a y-Q s u r f-E a-W \text { seep }-Q g w)
$$

with $S W t$ (final soil water content $(\mathrm{mm})$ ), $S W o$ (initial water content in the soil for plant uptake (mm)), Rday (daily rainfall (mm)), Qsurf (surface daily runoff (mm)), $E a$ (evapotranspiration $(\mathrm{mm})$ ), Wseep (percolation $(\mathrm{mm})$ ) and $Q g w$ (return flow $(\mathrm{mm}))$.

\section{2) SWAT-CUP and SUFI-2 algorithm}

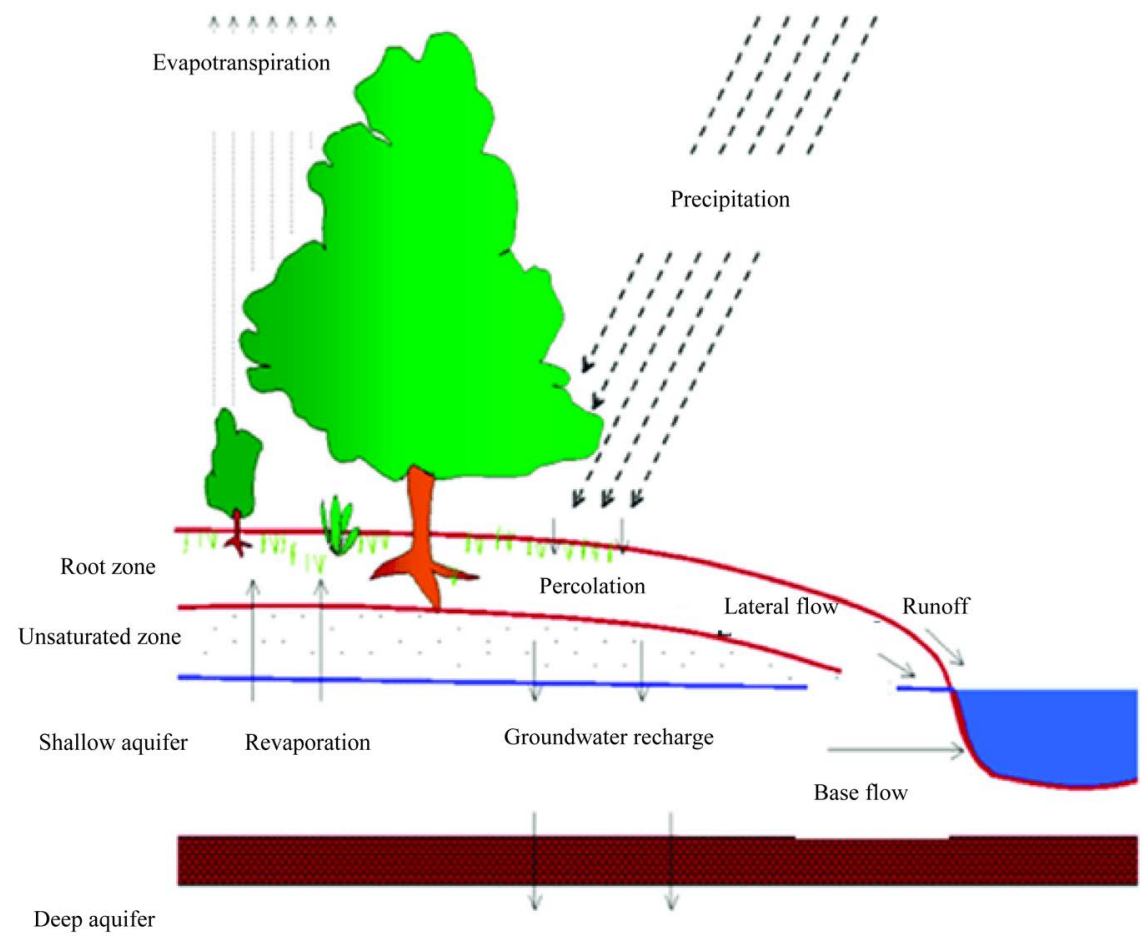

Figure 3. Schematic representation of hydrologic cycle in SWAT model (Neitsch et al., 2011). 
The implementation of the model cannot be done without some uncertainties. These uncertainties can be linked to the input data (measurement error and missing data), to the model itself (parameterization, process formulation) according to (Refsgaard et al., 2007; Schuol et al., 2008a; Bastin et al., 2013). Taking into account these uncertainties, it is essential to evaluate the difference and the similarity between the observed data and the simulated data, either by statistical criteria or graphically. The SWAT-CUP (SWAT-Calibration and Uncertainty Procedure) program is used for this purpose. It incorporates the calibration/ uncertainty and sensitivity analysis algorithms (Table 1). These are Sequential Uncertainty Fitting version 2 (SUFI-2) (Abbaspour et al., 2004; Abbaspour et al., 2007), Generalized Likelihood Uncertainty Estimation (GLUE) (Beven \& Binley, 1992), Particle Swarm Optimization ( PSO) (Eberhart \& Kennedy, 1995), Parameter Solution (PARASOL) (Van Grinsven \& Meixner, 2006) and Markov Chain Monte Carlo (MCMC) (Kuczera \& Parent, 1998).

Considering that SUFI2 takes into account all the sources of uncertainties (parameters, input of the conceptual model) (Yang et al., 2008), it was chosen to carry out the global sensitivity of the parameters. Two criteria of uncertainty govern this sensitivity analysis. These are the $\mathrm{P}$-factor calculated at $2.5 \%\left(\mathrm{X}_{1}\right)$ and the R-factor calculated at $97.5 \%\left(X_{u}\right)$ percentiles of the cumulative distribution of each simulated point. The quality of the fit is evaluated by measuring the uncertainty calculated from the percentage of measured data framed by the minimum and maximum values of the "95PPU". SUFI2 offers these two indicators (P factor and $\mathrm{R}$ factor) to quantify the inclusion of uncertainties and the best values to stop the simulations. The $\mathrm{P}$ factor represents respectively the percentage of measured data framed by the prediction uncertainty of $95 \%$ (95PPU), while the $\mathrm{R}$ factor represents the average thickness of the 95PPU band divided by the standard deviation of the measured data (Schuol et al., 2008a).

Table 1. Algorithms integrated in SWAT-CUP.

\begin{tabular}{cl}
\hline Algorithm & \multicolumn{1}{c}{ Description } \\
\hline SUFI-2 & $\begin{array}{l}\text { Uncertainty in parameters are expressed as ranges (uniform distributions). } \\
\text { (driving variables, conceptual model, parameters and measured data. }\end{array}$ \\
& After defining the generalized likelihood measure, a large number of parameter \\
sets are randomly sampled from the prior distribution and each parameter set is & assessed as either behavioral or non-behavioral through a comparison of the \\
likelihood measure with the given threshold value. Then, each behavioral & parameter is given a likelihood weight. Finally, the uncertainty is predicted. \\
PSO & $\begin{array}{l}\text { This algorithm represents a population based stochastic optimization technique. } \\
\text { It is initialized with a group of random particles (solutions) and then searches } \\
\text { for optima by updating generations. }\end{array}$ \\
PARASOL & $\begin{array}{l}\text { The PARASOL method uses objective functions (OF) into a global optimization } \\
\text { criterion (GOC), minimizes these OF or GOC using the Shuffle Complex } \\
\text { (SCE-UA) algorithm and performs uncertainty analysis. }\end{array}$ \\
MCMC & $\begin{array}{l}\text { MCMC generates samples from a random walk which adapts to the posterior } \\
\text { distribution }\end{array}$
\end{tabular}


The result of the simulation is considered very satisfactory when the P-factor reaches $100 \%$ and the R-factor close to zero (Abbaspour, 2013). In this study, three others criteria of performance were chosen. These criteria were the Nash-Sutcliffe coefficient (NSE), the coefficient of determination $\mathrm{R}^{2}$ and the PBIAS (percentage of bias which measures the average tendency of the simulated data to be larger or smaller than their counterparts (Gupta et al., 1999). If PBIAS equals 0 then the simulation is said to be accurate. However, when PBIAS is positive, it shows an underestimation of the model and negative values indicate an overestimation model bias (Gupta et al., 1999). The choice of PBIAS is justified by the fact that it is widely used in the literature and allows a more precise evaluation of the efficiency of the model (Coffey et al., 2004; Santhi et al., 2001; Chu et al., 2004; Gassman et al., 2007; Moriasi et al., 2007; Schuol et al., 2008b; Sintondji et al., 2008; Rollo, 2012; Vilaysane et al., 2015; Aouissi et al., 2016; Havrylenko et al., 2016, Maliehe et al., 2017; Molina-Navarro et al., 2017). The NSE coefficient (equation (2)) varies from $-\infty$ (for a very weak adjustment) to 1 (for a strong link between the observed and simulated values). The PBIAS is calculated according to equation (3). The values of PBIAS should be: PBIAS $< \pm 10$ for very good performance, $\pm 10<$ PBIAS $< \pm 15$ for good performance, $\pm 15<$ PBIAS $<$ \pm 25 for satisfactory performance and PBIAS $> \pm 25$ for unsatisfactory performance (Moriasi et al., 2007). Equation (4) allows us to calculate $R^{2}$, it varies from 0 to 1 (Tolson \& Shoemaker, 2004). A value greater than 0.5 reflects good agreement between observed and simulated data (Santhi et al., 2001).

$$
\begin{gathered}
\mathrm{NSE}=1-\left[\frac{\sum_{i=1}^{n}\left(Q_{i}^{\text {obs }}-Q_{i}^{\text {sim }}\right)^{2}}{\sum_{i=1}^{n}\left(Q_{i}^{\text {obs }}-Q^{\text {mean }}\right)^{2}}\right] \\
\mathrm{PBIAS}=\left[\frac{\sum_{i=1}^{n}\left(Q_{i}^{\text {obs }}-Q_{i}^{\text {sim }}\right) * 100}{\sum_{i=1}^{n}\left(Q_{i}^{\text {obs }}\right)^{2}}\right] \\
\mathrm{R}^{2}=\frac{\left(\sum_{i=1}^{n}\left(Q_{i}^{\text {obs }}-Q_{i}^{\text {sim }}\right)\left(Q_{i}^{\text {sim }}-\overline{Q_{i}^{\text {sim }}}\right)\right)^{2}}{\sum_{i=1}^{n}\left(Q_{i}^{\text {obs }}-\overline{Q_{i}^{\text {obs }}}\right)^{2} \sum_{i=1}^{n}\left(Q_{i}^{\text {sim }}-\overline{Q_{i}^{\text {sim }}}\right)^{2}}
\end{gathered}
$$

with $Q_{i}^{\text {obs }}$ observed flow, $Q_{i}^{\text {sim }}$ simulated flow, $Q^{\text {mean }}$ average observed flow, $\overline{Q_{i}^{o b s}}$ average observed flow and $\overline{Q_{i}^{\text {sim }}}$ average simulated flow.

\subsubsection{Model Set up and Streamflow Calibration and Validation}

The methodology adopted in this study is inspired by (Koua et al., 2019). The Lobo watershed in Nibéhibé covers an area of $6442.66 \mathrm{~km}^{2}$. The DEM is used to extract the boundaries of the watershed and the hydrographic network using QSWAT (SWAT in the QGIS interface). The D8 algorithm of (Jenson \& Domingue, 1998) was therefore used. First, an outlet was imposed at the Nibéhibé hydrometric station. The correctness of the watershed delineation was verified by overlaying the delineation results with high resolution satellite data from Google Earth. 31 sub-basins were obtained. Then, the hydro-statistical parame- 
ters of the climate data were calculated using SWAT's WGN parameter estimation tool (Essenfelder, 2016). Then, data relating to land use, soil maps and their physicochemical properties were integrated into the SWAT model. Reclassification of land use was then necessary to represent the different classes from the SWAT database. The hydrological response units (HRU, combination of a single type of land use, soil and slope) were then calculated. The runoff is estimated separately for each HRU and cumulated to reach the total runoff over the watershed. Thus, 163 HRUs were obtained using the multiple HRU option of SWAT. Once the HRUs are calculated, QSWAT will proceed to configure the various input data tables. These data are linked to soil data, hydrometeorological data, general data on sub-watersheds, HRUs, main channels of the watershed, groundwater and water use, water, watershed management, soil chemistry, wetlands, river water quality, septic tanks, different practices in the watershed, general water quality in the basin watershed and the master file of the watershed. These data relating to the different compartments of the watershed can be updated at any time as needed. At this stage, the hydrological behavior of the Lobo watershed can be simulated.

The flow data from the Nibéhibé gauging station were used for calibration and validation using SUFI-2 (Abbaspour et al., 2004; Abbaspour et al., 2007; Abbaspour, 2011). Ten (10) flow parameters were chosen: CN2 (SCS curve number, humidity condition II), SOL_AWC (available water capacity of the soil layer), ESCO (soil evaporation compensation factor), RCHRG_DP (deep aquifer percolation fraction), GW_REVAP (groundwater "revap" coefficient), ALPHA_BF (Base flow alpha factor), GWQMN (Threshold depth of water in the shallow aquifer required for return flow occurs), REVAPMN (Threshold depth of water in shallow aquifer for "revap" to occur), GW_DELAY (Groundwater delay) and CANMX (Maximum canopy storage). The setting in SWAT-CUP is done according to three types of change to be applied to the parameter: " ${ }_{-}$" means that the existing value of the parameter must be replaced by a given value, "a_" means that a given value is added to the value existing. Parameter value and "r." mean that an existing parameter value is multiplied by $(1+$ a given value). For example, if $\mathrm{CN} 2$ is changed by assigning " $r_{-}$", it becomes $r_{-} C N 2$. This means that the future simulated $\mathrm{CN} 2$ value is obtained by multiplying the current simulated value by (1+ a given $\mathrm{CN} 2$ value). The SWAT model was calibrated from 1982 to 1984 and valid for the period 1984-1987. 500 simulations were carried out.

\section{Results and Discussion}

\subsection{Results}

\subsubsection{Streamflow Parameter Global Sensitivity}

It emerges from this study that the parameters more sensitive to flow are GW_REVAP, GWQMN, RCHRG_DP, ESCO and CN2 (Table 2 and Table 3). However, one noticed that the most sensitive hydrological parameters to flow 
Table 2. Streamflow parameter global sensitivity.

\begin{tabular}{|c|c|c|c|c|c|}
\hline $\begin{array}{l}\text { Global } \\
\text { sensitivity } \\
\text { rank }\end{array}$ & Parameter & Parameter description & $\begin{array}{l}\text { Fitted } \\
\text { value }\end{array}$ & $\begin{array}{l}\text { Minimum } \\
\text { value }\end{array}$ & $\begin{array}{l}\text { Maximum } \\
\text { value }\end{array}$ \\
\hline 1 & v_GW_REVAP & $\begin{array}{l}\text { Groundwater } \\
\text { revaporation coefficient }\end{array}$ & 0.1649 & 0.02 & 0.2 \\
\hline 2 & a__GWQMN & $\begin{array}{l}\text { Treshold depth of water } \\
\text { in the shallow aquifer } \\
\text { required for return } \\
\text { flow to occur (mm) }\end{array}$ & -162 & -1000 & 1000 \\
\hline 3 & a_RCHRG_DP & $\begin{array}{c}\text { Deep aquifer } \\
\text { percolation fraction }\end{array}$ & -0.0205 & -0.05 & 0.05 \\
\hline 4 & $\mathrm{v \_}$ ESCO & $\begin{array}{l}\text { Soil evaporation } \\
\text { compensation factor }\end{array}$ & 0.5465 & 0.5 & 0.8 \\
\hline 5 & $\mathrm{r} \_\mathrm{CN} 2$ & $\begin{array}{l}\text { SCS runoff curve } \\
\text { number fonction }\end{array}$ & 0.081 & -0.1 & 0.1 \\
\hline
\end{tabular}

Table 3. Streamflow parameter global sensitivity (continued from Table 2).

\begin{tabular}{|c|c|c|c|c|c|}
\hline $\begin{array}{c}\text { Global } \\
\text { sensitivity } \\
\text { rank }\end{array}$ & Parameter & Parameter description & $\begin{array}{l}\text { Fitted } \\
\text { value }\end{array}$ & $\begin{array}{l}\text { Minimum } \\
\text { value }\end{array}$ & $\begin{array}{l}\text { Maximum } \\
\text { value }\end{array}$ \\
\hline 6 & a_GW_DELAY & Groundwater delay (days) & -28.83 & -30 & 60 \\
\hline 7 & a__REVAPMN & $\begin{array}{l}\text { Threshold depth of water } \\
\text { in the shallow aquifer for } \\
\text { "revap" to occur (mm) }\end{array}$ & 370.50 & -750.00 & 750.00 \\
\hline 8 & $\mathrm{v} \_$ALPHA_BF & Baseflow alpha factor (days) & 0.945 & 0.00 & 1.00 \\
\hline 9 & r__SOL_AWC & $\begin{array}{c}\text { Available water capacity } \\
\text { of the soil layer }\end{array}$ & -0.0143 & -0.05 & 0.05 \\
\hline 10 & $\mathrm{v}_{-}$CANMX & Maximum canopy storage & 14.174999 & 0.00 & 15.00 \\
\hline
\end{tabular}

are those of groundwater (GW_REVAP, GWQMN and RCHRG_DP). The analysis of these results makes it possible to highlight a probable link between groundwater and surface water in the region. The sensitivity of the coefficient GW_REVAP, GWQMN and RCHRG_DP in the model underlines the importance of the aquifer depth for water flow in the watershed.

\subsubsection{Streamflow Calibration and Uncertainty}

During the calibration period, the SWAT model simulates the flow almost perfectly with a very low variation $(-0.09 \%)$ (Table 4$)$. During the validation period, the model simulates an average monthly flow of $4.67 \mathrm{~m}^{3} / \mathrm{s}$ against $5.81 \mathrm{~m}^{3} / \mathrm{s}$ observed, i.e. a variation of $-1.14 \%$. There is therefore a slight underestimation of the model. The results showed good performance for the streamflow calibration (1982-1984) with the evaluation criteria $\mathrm{R}^{2}$, NSE and PBIAS respectively of 0.64, 0.64 and 3.1. Over the validation period (1984-1987), the model also showed good performance in the streamflow simulation for $\mathrm{R}^{2}$ and NSE of 0.84 
and 0.76 respectively as values. However, for the PBAIS criterion, the result was less good, but still remains satisfactory with a value of 19.6.

Figure 4 and Figure 5 clearly demonstrate this fact. The graph in Figure 4 shows that the model predictions generally follow the pattern of the observed data. But, we see that the peaks are not completely respected at the start of the

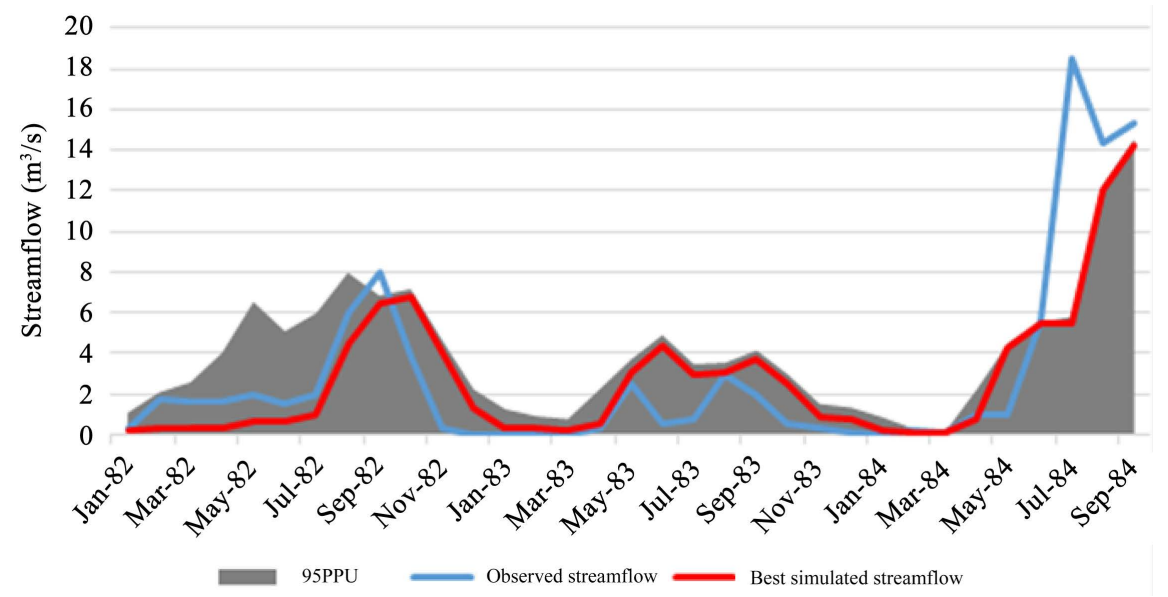

Figure 4. Streamflow calibration result at Nibéhibé hydrometric station.

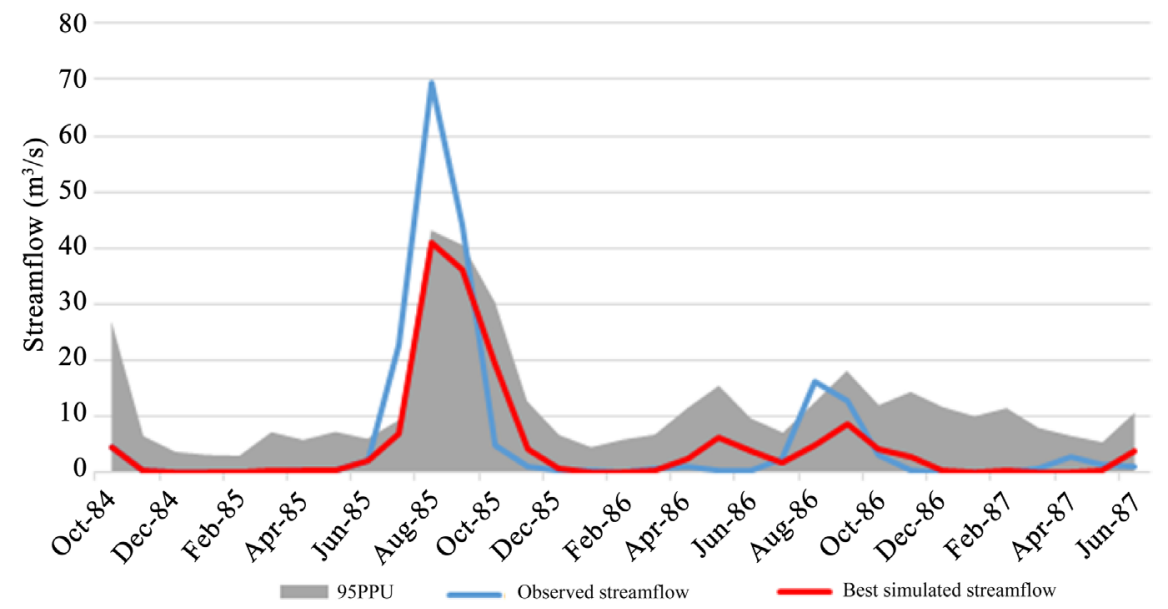

Figure 5. Streamflow validation result at nibéhibé hydrometric station.

Table 4. Calibration and validation results.

\begin{tabular}{ccc}
\hline Monthly flow and Performance criteria & Calibration (1982-1984) & Validation (1984-1987) \\
\hline Mean monthly observed streamflow $\left(\mathrm{m}^{3} / \mathrm{s}\right)$ & 2.89 & 5.81 \\
Mean monthly streamflow simulated $\left(\mathrm{m}^{3} / \mathrm{s}\right)$ & 2.80 & 4.67 \\
$\mathrm{R}^{2}$ & 0.64 & 0.84 \\
NSE & 0.64 & 0.76 \\
PBAIS & 3.1 & 19.6 \\
P-factor & 0.73 & 0.33 \\
R-factor & 0.64 & 0.58 \\
\hline
\end{tabular}


simulation as well as at the end. The prediction uncertainties are composed of two indices (P-factor and R-factor); a P-factor of 1 and R-factor of 0 is a simulation that exactly corresponds to measured data; however, this was not our case in this study. In this case, P-factor and R-factor were found to be 0.48 and 0.52 , respectively.

\subsection{Discussion}

According to results obtained in this study, one notices that the parameters most sensitive to stream flow are GW_REVAP, GWQMN, RCHRG_DP, ESCO and $\mathrm{CN} 2$. Comparing these results to recent studies, these results are in agreement with those obtained by (Anoh et al., 2017) in the Taabo watershed which borders with the Lobo watershed. Indeed, (Anoh et al., 2017) showed that hydrological parameters such as GWQMN, ESCO and CN2 are more sensitive to streamflow than GW_REVAP and RCHRG_DP. The sensitivity of ESCO and CN2 to streamflow has already been highlighted in western Mississippi river (Dakhlalla \& Parajuli, 2019). Also, CN2 indicates an influence of reducing the surface runoff caused by the precipitation (Xu et al., 2010; Strauch et al., 2012; Vu et al., 2012; Tuo et al., 2016). However, estimating the true values of CN2 and ESCO could be difficult because there are multiple CN2 and ESCO values that yield the same model performance. These results also emphasize the fact that the non-identifiability of a parameter does not necessarily mean that the parameter is not sensitive in the model (Shen et al., 2012). The $\mathrm{R}^{2}$, NSE and PBIAS coefficients of $0.64,0.64$ and 3.1, respectively, showed a satisfactory model performance during calibration period. Validation results show $0.84,0.76$ and 19.6 as values of $\mathrm{R}^{2}$, NSE and PBIAS respectively. According to (Moriasi et al., 2007), hydrological model has a satisfactory performance when $0.50 \leq \mathrm{NSE} \leq 0.65$, good performance for $0.65 \leq \mathrm{NSE} \leq 0.75$ and very good performance when 0.75 $\leq \mathrm{NSE} \leq 1.00$. During validation period, model results show a very good performance for $\mathrm{R}^{2}$ and NSE, but worse than PBIAS. These results agree with those obtained by (Anoh et al., 2018) in the Taabo watershed which borders with that of Lobo. For streamflow calibration and validation, these authors have obtained 0.7 as NSE and 0.6 as $R^{2}$ mean values respectively. A very good performance of the model according to the PBIAS is obtained over calibration period which is 3.1 (Moriasi et al., 2007). For discharge, P-factor $>0.7$ and R-factor $<1.5$ are considered acceptable in terms of prediction uncertainty (Abbaspour et al., 2015). $\mathrm{P}$-factor and R-factor obtained in this study over calibration period are 0.73 and 0.64 which are therefore very good because a value of $\mathrm{P}$-factor close to 1 and $\mathrm{R}$-factor $<1.5$ is desirable for the model to be perfect (Abbaspour et al., 2015). In validation period $\mathrm{P}$-factor is 0.33 and $\mathrm{R}$-factor has a value of 0.58 . This shows less good performance compared to calibration period. But, sometimes, a lower $\mathrm{P}$-factor can be achieved at the expense of a larger R-factor and vice-versa. Hence, when a balance is reached between the two factors the model can be acceptable (Abbaspour et al., 2015). The values obtained over validation period $(\mathrm{P}$-factor $=0.33$ and $\mathrm{R}$-factor $=0.58)$ indeed show a balance between these fac- 
tors. The prediction uncertainties are therefore acceptable. This situation comes from the fact that the model is very sensitive to the quality of the input data when the watershed is large (Moriasi et al., 2007; Koua et al., 2013; Koua et al., 2014). Because the entire watershed is covered by only one physical climatic station, it was essential to use climate data from satellite sources. However, these data are very often influenced by the weather. In cloudy weather, for example, the satellite often cannot record values or records them incorrectly because part of the radiation emitted by the sun is captured by clouds. Therefore, the radiation emitted from the ground to the satellite sensors is low. This situation doesn't provide all the information on land use. This could be the origin of phase differences between simulated and observed flood peaks. The DEM used has a spatial resolution of $30 \mathrm{~m}$ which can be a source of information loss. Therefore, a DEM with high resolution would be more suitable to improve model results. Additionally, satellite images used do not allow to identify varied vegetation cover of the watershed. This gap reduces HRU precision and, therefore impacts model predictions (Neitsch et al., 2011).

\section{Conclusion}

The study was carried out using the SWAT agro-hydrological model to study its performance to simulate water flow in the Lobo watershed in Nibéhibé. The flow calibration evaluation criteria showed good performance in general. Indeed, the evaluation criteria $\mathrm{R}^{2}$, NSE and PBIAS obtained were respectively 0.64, 0.64 and 3.1 in calibration period (1982-1984). The prediction uncertainties represented by P-factor and R-factor gave 0.73 and 0.64 over the same period. Validation results gave $0.84,0.76$ and 19.6 as values of $\mathrm{R}^{2}$, NSE and PBIAS respectively, $\mathrm{P}$-factor 0.33 and $\mathrm{R}$-fact or 0.58 . These values display a good performance by the model and prove the SWAT model is an appropriate tool for use in simulating flow in the Lobo watershed. Despite the limitations of the model linked to the quality and quantity of the input data, the results of this study constitute a solid basis that can be improved once a large database is available and serve as critical data in the fight against the eutrophication phenomenon throughout hydrological modeling in agricultural watersheds in Côte d'Ivoire. This work of water flow modeling in the Lobo watershed at Nibéhibé is essential for the efficient management of water resources. It is therefore a basis in the Lobo Reservoir eutrophication phenomenon study that should be taken into account by The Ivorian authorities.

\section{Acknowledgements}

This work was supported by the Fulbright African Research Scholar Program that enabled the completion of this study through the granting of a scholarship.

\section{Conflicts of Interest}

The authors declare no conflicts of interest regarding the publication of this paper. 


\section{References}

Abbaspour, K. C., Johnson, C. A., \& Van Genuchten, M. T. (2004). Estimating Uncertain Flow and Transport Parameters Using a Sequential Uncertainty Fitting Procedure. Vadose Zone Journal, 3, 1340-1352. https://doi.org/10.2136/vzj2004.1340

Abbaspour, K. C., Rouholahnejad, E., Vaghefi, S., Srinivasan, R., Yang, H., \& Kløve, B. (2015). A Continental-Scale Hydrology and Water Quality Model for Europe: Calibration and Uncertainty of a High-Resolution Large-Scale SWAT Model. Journal of Hydrology, 524, 733-752. https://doi.org/10.1016/j.jhydrol.2015.03.027

Abbaspour, K. C. (2011). Swat-Cup2: SWAT Calibration and Uncertainty Programs Manual (Version 2). Swiss Federal Institute of Aquatic Science and Technology.

Abbaspour, K. C. (2013). SWAT-CUP 2013: SWAT Calibration and Uncertainty Programs-A User Manual. Swiss Federal Institute of Aquatic Science and Technology.

Abbaspour, K. C., Yang, J., Maximov, I., Siber, R., Bogner, K., Mieleitner, J., Zobrist, J., \& Srinivasan, R. (2007). Modelling Hydrology and Water Quality in the Pre-Alpine/Alpine Thur Watershed Using SWAT. Journal of Hydrology, 333, 413-430.

https://doi.org/10.1016/j.jhydrol.2006.09.014

Anoh, K., Koua, T., Eblin, S., Kouamé, K., \& Jourda, J. (2017). Modelling Freshwater Availability Using SWAT Model at a Catchment-Scale in Ivory Coast. Journal of Geoscience and Environment Protection, 5, 70-83. https://doi.org/10.4236/gep.2017.513005

Anoh, K., Koua, T., Kouamé, K., Jourda J., \& Laurent, F. (2018). Modelling Water Flow in a Complex Watershed in Humid a Tropical Area Using SWAT: A Case Study of Taabo Watershed in Ivory Coast. International Journal of River Basin Management, 16, 157-167. https://doi.org/10.1080/15715124.2017.1387122

Aouissi, J., Benabdallah, S., Chabaâne, Z., \& Cudennec, C. (2016). Evaluation of Potential Evapotranspiration Assessment Methods for Hydrological Modelling with SWATApplication in Data-Scarce Rural Tunisia. Agricultural Water Management, 174, 39-51. https://doi.org/10.1016/j.agwat.2016.03.004

Arnold, J. G., Srinivasan, R., Muttiah, R., \& Williams, J. R. (1998). Large Area Hydrologic Modeling and Assessment. Part I: Model Development. Journal of the American Water Resources Association, 34, 73-89. https://doi.org/10.1111/j.1752-1688.1998.tb05961.x

Avenard, J. M. (1971). Geomorphology Aspect. In J. M. Avenard, M. Eldin, G. Girard, J. Sircoulon, P. Touchebeuf, J. L. Guillaumet, E. Adjanohoun, \& A. Perraud (Eds), The Natural Environment of Côte d'Ivoire (pp. 11-72). Office de la Recherche Scientifique et Technique d'Outre-Mer. (In French)

Babaei, H., Nazari-Sharabian, M., Karakouzian, M., \& Ahamad, S. (2019). Identification of Critical Source Areas (CSAs) and Evaluation of Best Mnagement Practices (BMPs) in Controlling Eutrophication in the Dez River Basin. Envrironments, 6, Article No. 20. https://doi.org/10.20944/preprints201901.0171.v1

Bhagowati, B., \& Ahamad, U., K. (2019). A Review on Lake Eutrophication Dynamics and Recent Developments in Lake Modeling. Ecohydrology \& Hydrobiology, 19, 155-166. https://doi.org/10.1016/j.ecohyd.2018.03.002

Bastin, L., Cornford, D., Jones, R., Heuvlink, G., Pebesma, E., Stasch, C., Nativi, S., Mazzetti, P., \& Williams, M. (2013). Managing Uncertainty in Integrated Environmental Modelling: The UncertWeb Framework. Environmental Modelling \& Software, 39, 116-134. https://doi.org/10.1016/j.envsoft.2012.02.008

Beven, K., \& Binley, A. (1992). The Future of Distributed Models-Model Calibration and Uncertainty Prediction. Hydrological Processes, 6, 279-298.

https://doi.org/10.1002/hyp.3360060305 
Brou, Y. T. (2005). Climate, Socio-Economic Changes and Landscapes in Côte d'Ivoire (Summary Thesis Submitted with a View to Obtaining the Authorization to Supervise Research). University of Science and Technology. (In French)

Chocat, B. (1997). Urban Planning and Hydrology. La Houille Blanche, 83, 12-19. (In French) https://doi.org/10.1051/lhb/1997057

Chu, T. W., Shirmohammadi, A., Montas H., \& Sadeghi A. (2004). Evaluation of the SWAT Model's Sediment and Nutrient Components in the Piedmont Physiographic Region of Maryland. Transactions of the ASAE, 47, 1523-1538. https://doi.org/10.13031/2013.17632

Coffey, M. E., Workman, S. R., Taraba, J. L., \& Fogle, A. W. (2004). Statistical Procedures for Evaluating Daily and Monthly Hydrologic Model Predictions. Transaction of the ASABE, 47, 59-68. https://doi.org/10.13031/2013.15870

Dakhlalla, A. O., \& Parajuli, B. P. (2019). Assessing Model Parameters Sensitivity and Uncertainty of Streamflow, Sediment, and Nutrient Transport Using SWAT. Information Processing in Agriculture, 6, 61-72. https://doi.org/10.1016/j.inpa.2018.08.007

Dié (2006). Strengthening of the Drinking Water Supply to the Daloa City from the Buyo Dam in Côte d'Ivoire. Master Thesis, EIER (Inter-State School in Rural Equipment). (In French).

Eberhart, R. C., \& Kennedy, J. (1995). A New Optimizer Using Particle Swarm Theory. Proceedings of the 6th International Symposium on Micro Machine and Human Science, Nagoya, 4-6 October 1995, 39-43. https://doi.org/10.1109/MHS.1995.494215

Essenfelder, A. H. (2016). SWAT Weather Database: A Quick Guide (Version: v.0.16.07). Technical Report, Centro Euro-Mediterraneo sui CambiamentiClimatici-CCMC, Lecce, Italy, $14 \mathrm{p}$.

Garnier, J., Ramarson, A., Billen, G., Thery, S., Thiery, D., Thieu, V., Minaudo, C., \& Moatar, F., (2018). Nutrients Inputs and Hydrology Together Determine Biogeochemical Status of the Loire River (France): Current Situation and Possible Future Scenarios. Science of the Total Environment, 637-638, 609-624. https://doi.org/10.1016/j.scitotenv.2018.05.045

Gassman, P. W., Reyes, M. R., Green, C. H., \& Arnold, J. G. (2007). The Soil and Water Assessment Tool: Historical Development, Applications, and Future Research Directions. Transactions of the ASABE, 50, 1211-1250. https://doi.org/10.13031/2013.23637

Gupta, H. V., Sorooshian, S., \& Yapo, P. O. (1999). Status of Automatic Calibration for Hydrologic Models: Comparison with Multilevel Expert Calibration. Journal of Hydrologic Engineering, 4, 135-143. https://doi.org/10.1061/(ASCE)1084-0699(1999)4:2(135)

Havrylenko, S. B., Bodoque, J. M., Srinivasan, R., Zucarelli, G. V., \& Mercuri, P. (2016). Assessment of the Soil Water Content in the Pampas Region Using SWAT. Catena, 137, 298-309. https://doi.org/10.1016/j.catena.2015.10.001

Jenson, S., \& Domingue, J. (1998). Extracting Topographic Structure from Digital Elevation Data for Geographic Information System Analysis. Photogrammetric Engineering and Remote Sensing, 54, 1593-1600.

Komelan, Y. (1999). Eutrophication of Water Reservoirs in Côte d'Ivoire and Management of Their Watershed: Case of Lobo in Daloa. Master Thesis, EIER (Inter-State School in Rural Equipment). (In French)

Koua, T. J., Jourda, J. P., Kouame, K. J., \& Anoh, K. A. (2013). Assessment of Sediment and Pollutants in Buyo Lake, Ivory Coast, Using SWAT (Soil and Water Assessment 
Tool) Model. Journal of Chemistry and Chemical Engineering, 7, 1054-1059.

Koua, T. J., Jourda, J .P., Kouamé, K. J., Anoh, K. A., N’dri, W. K., Lazar, G., \& Lane, S. (2014). Effectiveness of Soil and Water Assessment Tool Model to Simulate Water Flow in a Large Agricultural Complex Watershed: Case of Buyo Lake Basin, West of Côte d'Ivoire. Environmental Engineering and Management Journal, 13, 1735-1742 https://doi.org/10.30638/eemj.2014.193

Koua, T. J., Kouassi, K. H., \& Anoh, K. A. (2019). Analysis of the SWAT (Soil and Water Assessment Tool) Semi-Distributed Model Input Data for the Hydrological Simulation of the Lobo Water Reservoir (Central West of Côte d'Ivoire). Journal of Geography, Environment and Earth Science International, 23, 1-20. https://doi.org/10.9734/jgeesi/2019/v23i430182

Kuczera, G., \& Parent, E. (1998). Monte Carlo Assessment of Parameter Uncertainty in Conceptual Catchment Models: The Metropolis Algorithm. Journal of Hydrology, 211, 69-85. https://doi.org/10.1016/S0022-1694(98)00198-X

Maïga, A., Denyigba, K., \& Allorent, J. (2001). Eutrophication of Small Water Reservoirs in West Africa: Causes and Consequences: Case of the Water Reservoir on the Lobo in Ivory Coast. Sud Sciences \& Technologies, 7, 16-29. (In French)

Maliehe, M., \& Mulungu, D. M. (2017). Assessment of Water Availability for Competing Uses Using SWAT and WEAP in South Phuthiatsana Catchment, Lesotho. Physics and Chemistry of the Earth, Parts $A / B / C, 100,305-316$. https://doi.org/10.1016/j.pce.2017.02.014

Moal, L., M., Gascuel-Odoux, C., Menesguen, A., Souchon, Y., Etrillard, C., Levain, A., Moatar, F. et al. (2019). Eutrophication: A New Wine in an Old Bottle? Science of the Total Enviornment, 651, 1-11. https://doi.org/10.1016/j.scitotenv.2018.09.139

Molina-Navarro, E., Anderson, H., Nielsen, A., Thodsen, H., \& Trolle, D. (2017). The Impact of the Objective Function in Multi-Site and Multi-Variable Calibration of the SWAT Model. Environmental Modelling \& Software, 93, 255-267. https://doi.org/10.1016/j.envsoft.2017.03.018

Moriasi, D. N., Arnold, J. G., Van Liew, M. W., Bingner, R. L., Harmel, R. D., \& Veith, T. L. (2007). Model Evaluation Guidelines for Systematic Quantification of Accuracy in Watershed Simulations. Transactions of the ASABE, 50, 885-900. https://doi.org/10.13031/2013.23153

Nachtergaele, F., Velthuizen, H. V., \& Verest L. (2009). Harmonized World Soil Database (Version 1.1, $38 \mathrm{p}$ ). http://www.fao.org/fileadmin/templates/nr/documents/HWSD/HWSD_Documentatio $\underline{\text { n.pdf }}$

Neitsch, S. L., Arnold, J. G., Kiniry, J. R., \& Williams, R. (2005). Soil and Water Assessment Tool (Version 2005, 494 p). Theoretical Documentation, Agricultural Research Service, Grassland, Soil and Water Research Laboratory.

Neitsch, S. L., Arnold, J. G., Kiniry, J. R., \& Williams, J. R. (2011). Soil and Water Assessment Tool Theoretical Documentation (Version 2009, p. 618). Technical Report, Texas Water Resources Institute, College Station.

Ohou-Yao, M., Séka, A., Mambo, V., Yapo, O., Konan, K., \& Houénou, P. (2014). Contamination of Traditional Well Water by Nitrates in the Lobo Watershed (Buyo, Southwest of Côte d'Ivoire). Journal of Applied Biosciences, 78, Article No. 6654. (In French) https://doi.org/10.4314/jab.v78i1.11

Refsgaard, J. C. (1997). Parameterization, Calibration, and Validation of Distributed Hydrological Models. Journal of Hydrology, 198, 69-97.

https://doi.org/10.1016/S0022-1694(96)03329-X 
Refsgaard, J. C., \& Storm, B. (1996). Construction, Calibration, and Validation of Hydrological Models. In M. B. Abbot, \& J. C. Refsgaard (Eds.), Distributed Hydrologic Modeling (pp. 41-54). Springer. https://doi.org/10.1007/978-94-009-0257-2_3

Refsgaard, J. C., Van der Sluijs, J. P., Højberg, A. L., \& Vanrolleghem, P. A. (2007). Uncertainty in the Environmental Modelling Process-A Framework and Guidance. Environmental Modelling \& Software, 22, 1543-1556.

https://doi.org/10.1016/j.envsoft.2007.02.004

Rollo, N. (2012). Modeling of Diffuse Pollution Dynamics in the Auray River Watershed. Quantification, Characterization and Management of Terrigenous Nutrient Inputs. PhD Thesis in Geography, University of Nantes. (In French)

Santhi, C., Arnold, J. G., Williams, J. R., Dugas, W. A., \& Srinivasan, R. (2001). Validation of the SWAT Model on a Large River Basin with Point and Nonpoint Sources. Journal of the American Water Resources Association, 37, 1169-1188.

https://doi.org/10.1111/j.1752-1688.2001.tb03630.x

Schuol, J., Abbaspour, K. C., Srinivasan, R., \& Yang, H. (2008a). Modeling Blue and Green Water Availability in Africa. Water Resources Research, 44, Article No. W07406. https://doi.org/10.1029/2007WR006609

Schuol, J., Abbaspour, K. C., Srinivasan, R., \& Yang, H. (2008b). Estimation of Freshwater Availability in the West African Sub-Continent Using the SWAT Hydrologic Model. Journal of Hydrology, 352, 30-49. https://doi.org/10.1016/j.jhydrol.2007.12.025

Shen, Z., Chen, L., Liao, Q., Liu, R., \& Hong, Q. (2012). Impact of Spatial Rainfall Variability on Hydrology and Nonpoint Source Pollution Modeling. Journal of Hydrology, 472-473, 205-215. https://doi.org/10.1016/j.jhydrol.2012.09.019

Sintondji, L. O., Awoye, H. R., \& Agbossou, K. E. (2008). Modeling of the Hydrological Balance of the Kou Watershed in Center-Benin: Contribution to the Sustainable Management of Water Resources. Bulletin of Agronomic Research of Benin, 59, 35-48. (In French)

Strauch, M., Bernhofer, C., Koide, S., Volk, M., Lorz, C., \& Makeschin, F. (2012). Using Precipitation Data Ensemble for Uncertainty Analysis in SWAT Streamflow Simulation. Journal of Hydrology, 414-415, 413-424. https://doi.org/10.1016/j.jhydrol.2011.11.014

Tolson, B. A., \& Shoemaker, C. A. (2004). Watershed Modeling of the Cannonsville Basin Using SWAT 2000, Model Development, Calibration and Validation for the Prediction of the Flow, Sediment and Phosphorus Transport to the Cannonsville Reservoir (p. 159). Technical Report, School of Civil and Environmental Engineering, Cornell University.

Tuo, Y., Duan, Z., Disse, M., \& Chiogna, G. (2016). Evaluation of Precipitation Input for SWAT Modeling in Alpine Catchment: A Case Study in the Adige River Basin (Italy). Science of the Total Environment, 573, 66-82.

https://doi.org/10.1016/j.scitotenv.2016.08.034

Van Griensven, A., \& Meixner, T. (2006). Methods to Quantify and Identify the Sources of Uncertainty for River Basin Water Quality Models. Water Science and Technology, 53, 51-59. https://doi.org/10.2166/wst.2006.007

Vilaysane, B., Takara, K., Luo, P., Akkharath, I., \& Duan, W. (2015). Hydrological Stream Flow Modelling for Calibration and Uncertainty Analysis Using SWAT Model in the Xedone River Basin, Lao PDR. Procedia Environmental Sciences, 28, 380-390. https://doi.org/10.1016/j.proenv.2015.07.047

Vinçon-Leite, B., \& Casenave, C. (2019). Modelling Eutrophication in Lake Ecosystem: A Review. Science of the Total Environment, 651, 2985-3001. 
https://doi.org/10.1016/j.scitotenv.2018.09.320

Vu, M. T., Srinivasan, R., \& Liong, S. Y. (2012). SWAT Use of Gridded Observations for Simulating Runoff-A Vietnam River Basin Study. Hydrology and Earth System Sciences, 16, 2801-2811. https://doi.org/10.5194/hess-16-2801-2012

Wischmeier, W. H., \& Smith, D. D. (1978). Predicting Rainfall Erosion Losses (58 p). Agriculture Handbook No. 537, United States Department of Agriculture, Science and Education Administration.

Xu, H., Taylor, R. G., Kingston, D. G., Jiang, T., Thompson, J. R., \& Todd, M. C. (2010). Hydrological Modeling of River Xiangxi Using SWAT2005: A Comparison of Model Parameterizations Using Station and Gridded Meteorological Observations. Quaternary International, 226, 54-59. https://doi.org/10.1016/j.quaint.2009.11.037

Yang, J., Reichert, P., Abbaspour, K. C., Xia, J., \& Yang, H. (2008). Comparing Uncertainty Analysis Techniques for a SWAT Application to Chaohe Basin in China. Journal of Hydrology, 358, 1-23. https://doi.org/10.1016/j.jhydrol.2008.05.012 